\title{
Particle flux beneath fast ice in the shallow southwestern Beaufort Sea, Arctic Ocean
}

\author{
Andrew G. Carey, Jr. \\ College of Oceanography, Oregon State University, Corvallis, Oregon 97331, USA
}

\begin{abstract}
Flux of organic particulate materials under sea ice to the benthic environment was measured in the nearshore Arctic Ocean during spring 1980. Downward flux of organic carbon started early in the spring and continued at fairly uniform but low levels (approximately $1 \%$ of daily carbon production of ice algae) from April until early June. Particulate organic nitrogen flux tended to be low and erratic. Fecal pellets from 2 crustacean species were among the few recognizable large particles. The amphipod Pseudalibrotus (= Onisimus) litoralis, normally a benthic species, lives in spring on the undersurface of sea ice in the shallow polar environment. Collected pellets from adults decreased through spring, while those from juveniles increased until 5 Jun when their flux declined markedly. Late in spring these pellets contained primarily pennate diatom frustules from the ice algal bloom. Crustacean molts and Mysis relicta fecal pellets were also present, particularly in April and early May. The sinking particles were derived from both the pelagic and ice environments, although most of the material appeared to be from the ice biota. Data suggest that particles falling from the productive ice community during spring are a carbon source for the benthos; one that is small but available earlier than that from phytoplanktonic or benthic microalgal production.
\end{abstract}

\section{INTRODUCTION}

The ice-covered Arctic Ocean supports a restricted phytoplankton growing season limited primarily by low insolation at high latitudes and the shading effect of sea ice and snow cover (Horner 1985). Scattered data suggest that annual primary production is low (Nemoto \& Harrison 1981, Subba Rao \& Platt 1984) with no spring phytoplankton bloom (Horner 1984). During the sunlit spring when snow cover is scant or is melting, a bloom of pennate ice diatoms develops in the lowermost layers of the ice before significant biological activity occurs in the water column. In the Arctic the ice layer, in which the pennate diatoms bloom, is 2 to $3 \mathrm{~cm}$ thick and is soft. The diatoms in this layer are distributed in patches, but are vertically concentrated (Horner 1985).

Meiofaunal and macrofaunal invertebrates become associated with these ice algal blooms and are abundant during spring (Mel'nikov \& Kulikov 1980, Carey \& Montagna 1982, Cross 1982, Kern \& Carey 1983, Carey 1985). An extended food web is based on the microalgae, and larval and juvenile invertebrates utilize the environment as a nursery ground (Carey 1985. Grainger et al. 1985). Conover et al. (1986) suggest that planktonic calanoid copepods may use the ice algal bloom as a food source. The dominant macrofaunal amphipod in the ice community over shallow water, Pseudalibrotus (= Onisimus) Litoralis, utilizes the under-ice substrate as a feeding and nursery ground; it migrates to the ice in early spring where it feeds and releases its young. During spring $1980, P$. litoralis was 15.4 times more abundant $\left(7719100 \mathrm{~m}^{-3}\right.$ vs, $\left.500100 \mathrm{~m}^{-3}\right)$ in the lower 2 to $3 \mathrm{~cm}$ of ice than at the water-sediment interface (Boudrias \& Carey unpubl.). At ice break-up it migrates to the sea floor and lives as a member of the benthic community at depths of 10 to $20 \mathrm{~m}$ (Carey et al. 1981). Analyses of the gastro-intestinal tract and functional morphological studies indicate that $P$. litoralis is an omnivore while in the ice environment (Carey \& Boudrias 1987). This lysianassid species feeds as a scavenger at the ice under-surface on macro- and meiofaunal crustaceans early in the spring and then apparently shifts its diet to ice diatoms when the spring bloom of ice microalgae becomes intense.

Over shallow water on the inner continental shelf, benthic forms are the dominant members of the fast ice macrofauna, while over deeper water the macrofauna are pelagic in origin (Carey 1985). In the food-poor Beaufort Sea (Nemoto \& Harrison 1981) the ice biotic community with its dense ice algal bloom and its 
stabilized environment becomes an early source of nutrition (Dunbar 1977, Booth 1984). It has been hypothesized that in shallow water much of the algal production melts off the ice under-surface early in the summer and falls to the bottom where the benthos can utilize it as a food source (Golikov \& Scarlato 1973, Green 1976. Alexander 1980, 1981. Horner \& Schrader 1982). The ice meiofauna consists primarily of nematodes and cyclopoid and harpacticoid copepods, while the macrofauna is almost entirely comprised of gammarid amphipods (Cross 1982, Carey 1985, Boudrias \& Carey unpubl.).

The purpose of this study was to investigate the role of the spring cryopelagic community in the arctic oceanic ecosystem by determining the energetic links between the fast ice subsurface and the sea floor. As detailed by such researchers as Honjo (1980) and Suess (1980), large particles account for a significant portion of the downward flux of sediments and organic carbon and organic nitrogen in deep oceanic environments. For this study in the shallow Beaufort Sea, Iarge particles were collected by traps just above the sediments beneath fast sea ice to evaluate the hypothesis that falling particulate material provides an early and significant food source for the benthos.

\section{STUDY AREA}

Research was conducted during spring 1980 at a semi-permanent study site $\left(70^{\circ} 24^{\prime} \mathrm{N}, 147^{\circ} 31.4^{\prime} \mathrm{W}\right)$, $0.4 \mathrm{~km}$ north of Narwhal Island in the western Beaufort Sea (Fig. 1). The Alaskan Beaufort Sea continental shelf is narrow and shallow with the shelf break at 70 to
$80 \mathrm{~m}$ (Barnes \& Reimnitz 1974, Reimnitz \& Barnes 1974). Continental runoff is little and very seasonal, and the sedimentation rate is low. Carey et al. (1984) reported that the August (1976) sediment characteristics at the Narwhal Island study site are $0.3 \%$ gravel, $85.8 \%$ sand, $7.0 \%$ silt, and $6.9 \%$ clay with $0.08 \%$ organic carbon by weight. The principal lunar tides are mixed and primarily diurnal, and their amplitude is small; at Point Barrow, the western boundary of the Beaufort Sea, the total range measures $4.7 \mathrm{~cm}$ (Matthews 1981). Surge motions owing to meteorological events can cause sea level changes that are 10 times greater than those caused by astronomical tides.

Sea ice covers the entire Beaufort Sea shelf off northern Alaska for 9 to 10 mo of the year (Reimnitz et al. 1978). The seasonal pack ice retreats to the outer shelf during summer, although in some years ice is continuous in the seasonal sea ice zone from the shoreline to the polar icepack in the Central Arctic Basin for all 12 mo. During the ice-covered months coastal ice is anchored to the bottom in 10 to $20 \mathrm{~m}$ of water by multiyear ice masses with deep keels. Bottom-fast ice occurs several $\mathrm{km}$ offshore of Narwhal Island. The seasonal pack ice generally extends to the shelf edge and upper slope; the polar pack ice of the Arctic Basin is found beyond the continental shelf (Kovacs \& Mellor 1974).

Bottom currents on the inner shelf seaward of Narwhal Island are slight during the ice-covered season, particularly beneath fast ice close to the island where presumably friction from the ice and the shallow sea floor slows water movement (Aagaard 1984). Records taken from 2 current meters suspended over $3 \mathrm{wk}$ at $10 \mathrm{~m}$ depth in $27 \mathrm{~m}$ and $38 \mathrm{~m}$ of water beneath fast ice north of Narwhal Island during 1976 demonstrate that

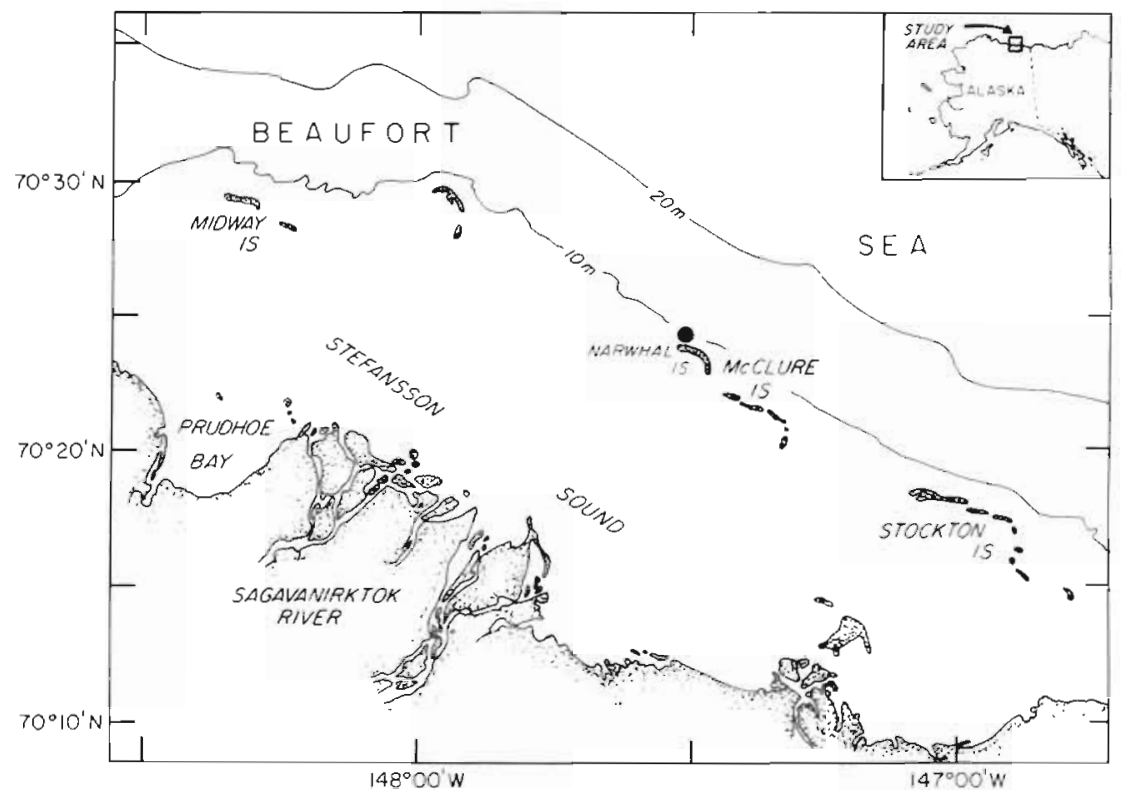

Fig. 1. Location of the stmi-permanent dive station, Sea Ice- 80 (mindicated by dot) $70^{\circ} 24^{\prime} \mathrm{N}, 147^{\circ} 31.4^{\prime} \mathrm{W}, 0.4 \mathrm{~km}$ north of Narwhal Island, Alaski, southwestern Beaufort Si:d 
Fig. 2. (A) PVC particle trap (exploded view) illustrating component parts: 1, protective cap; 2, collecting cylinder; 3 , rubber $\mathrm{O}$-ring; 4, glass-fiber filter; 5, perforated PVC filter bed 6 , base; 7 , drainage valve. (B) Bottomdeployed trap array with 4 cylinders. Distance between cylinders is $18.5 \mathrm{~cm}$ (circumferentially) and $31.0 \mathrm{~cm}$ (diagonally). Height above the bottom is $75.4 \mathrm{~cm}$
A

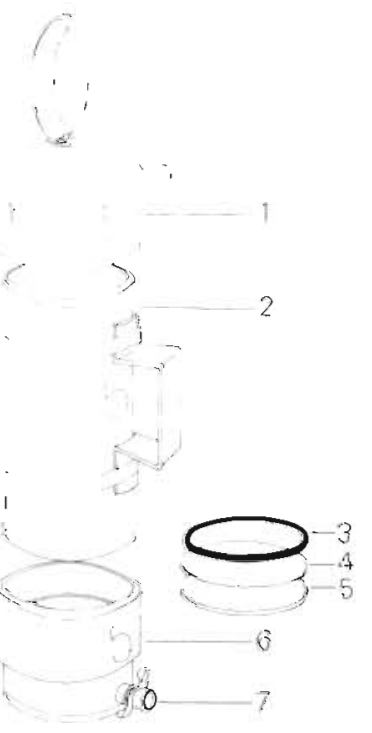

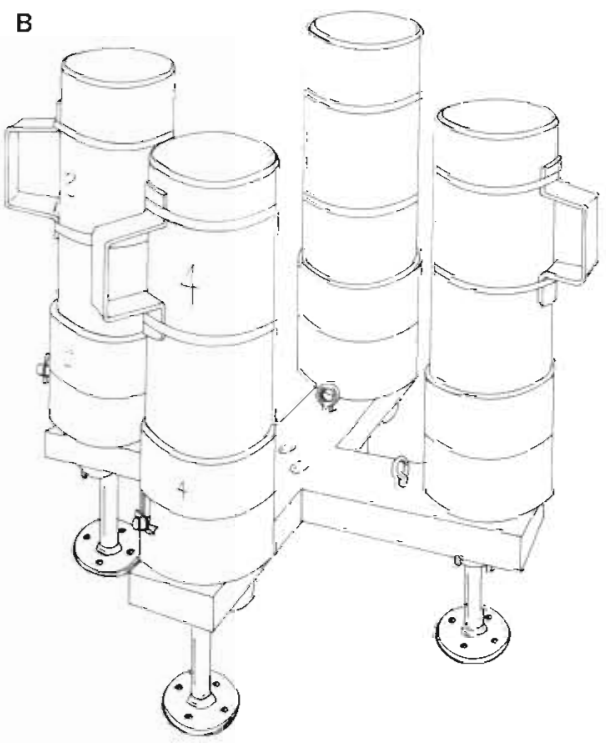

B currents were negligible at the shallowest station (Aagaard 1984). The mean flow was calculated at $0.3 \mathrm{~cm} \mathrm{~s}^{-1}$ with no net motion; individual current events never exceeded $10 \mathrm{~cm} \mathrm{~s}^{-1}$ even at the $38 \mathrm{~m}$ station nearer the seaward edge of the fast ice.

\section{MATERIAL AND METHODS}

Settled particles were collected within about $0.8 \mathrm{~m}$ of the sediment-water interface with particle traps that had a collection cylinder, $13.1 \mathrm{~cm}$ wide and $39 \mathrm{~cm}$ high (Fig. 2A). The aspect ratio of this chamber was close to the $3: 1$ configuration that has been considered best for minimizing resuspension by water turbulence (Bloesch \& Burns 1980, Gardner 1980). The upper rim was bevelled to achieve a definable collecting area of $134.78 \mathrm{~cm}^{2}$. A precombusted, preweighed glass fiber filter (Mead Corp., South Lee, Massachusetts, USA) was clamped at the base of each collecting chamber over a porous filter bed, made from a plastic (PVC) plate. Water was drained through a valve in a smaller lower chamber (13.1 cm wide, $7.7 \mathrm{~cm}$ high), and particles were retained on the glass fibers. The total filter diameter was $14 \mathrm{~cm}$, and the pore size $0.8 \mu \mathrm{m}$, with $96 \%$ efficiency at zero loading (Bishop \& Edmond 1976).

To minimize bacterial multiplication and the resulting biological degradation of the sample, sodium azide crystals were added to the lower chamber $(13.1 \mathrm{~cm}$ wide, $7.7 \mathrm{~cm}$ high) in small cotton bags beneath the filter bed in each trap before deployment (Honjo 1978). A dense brine solution was maintained by placing a small salt block under the filter bed in the traps. The brine solution helped to stabilize the water in the cylinders (Knauer \& Martin 1981). The azide and salt, upon dissolving, diffused through the filter base plate and the glass fiber filter bed into the bottom of the upper cylinder throughout the deployment period. (The darkcolored sodium azide was usually detectable within the trap upon retrieval.)

Eight traps, 4 on each of 2 weighted, wooden frames, were deployed by SCUBA divers 6 times from 13 Apr to 31 May 1980 (Fig. 2B). The traps were deployed on the sediment surface to the south of the dive hole in a sector of the study site chosen to have minimal disturbance from other diving operations undertaken for the Sea Ice-80 studies (e.g. Horner \& Schrader 1982, Kern \& Carey 1983, Carey \& Boudrias 1987). At deployment the cylinders contained Millipore-filtered seawater and were capped to minimize contamination (Fig. 2A). The caps were removed by the divers once the trap arrays were in place. Before retrieval the caps were replaced in situ.

In the field laboratory onshore at Prudhoe Bay, Alaska, the interior of each cylinder was washed down with Millipore-filtered fresh water and the remaining water was pulled through the glass-fiber pad by gentle suction. The particle traps were disassembled and the filters removed in a protective hood constructed of polyethylene sheeting. With the aid of forceps, each filter was carefully placed in a separate, prelabeled, sterile, plastic Petri dish for transport to the laboratory at Oregon State University. The filters and particles were stored deep-frozen $\left(-20^{\circ} \mathrm{C}\right)$.

Laboratory analyses included identification of particle type, qualitative composition, large particle counts, total particle weights on the filters (constant dry wt.), and organic carbon and nitrogen content. These data were then used to calculate the fluxes of mass, particle types, carbon, and nitrogen to the shallow sea floor. Three (of the 8) filters were analysed from each collec- 
tion period. Initially, ripped or otherwise disturbed filters were discarded and filters to be analysed were chosen randomly from the remainder.

Large-particle counts were made on the whole thawed filters with $6 \times$ magnification under a dissecting microscope without removing the filters from their protective Petri dishes. Particles were counted and measured with an ocular micrometer. A number of crustaceans in the collections, preserved in good shape, were assumed to be 'swimmers' (Knauer et al. 1979). These specimens were picked off the filter surfaces and discarded.

The total mass of particles on each filter was measured by first drying the filter to constant weight in an oven at $65^{\circ} \mathrm{C}$, then weighing to the nearest $0.001 \mathrm{~g}$. Contamination from sand particles stirred up by the SCUBA divers was evident in samples collected early in the series and somewhat affected the weights for collections from the first 2 deployments. For the salt correction three $0.595 \mathrm{~cm}^{2}$ subsamples were cut randomly with a cork borer from each of the undisturbed filters and soaked in $10.0 \mathrm{ml}$ of $0.3 \mathrm{~N} \mathrm{HCl}$. The magnesium concentrations in the filtrate were measured against dilute seawater standard by flame spectrophotometry. The salt-weight corrections were then calculated based on the magnesium content.

Carbon and nitrogen in particles contained on the collection filters were measured by elemental CHN analyzer (Perkin-Elmer, Model $240 \mathrm{C}$ ) in four $1.629 \mathrm{~cm}^{2}$ subsample filter disks removed by cork-borer from each filter. For study of the large particles by scanning electron microscopy (SEM), subsample disks $\left(0.595 \mathrm{~cm}^{2}\right)$ were removed from areas of interest on the filters. These were dried, mounted on aluminum studs and sputter-coated with Au/Pd. They were then examined with an SEM (International Scientific Instruments Mini-SEM, Model MSM-2), and particles were photographed at appropriate magnifications.

Fecal pellets, collected in the traps, were compared with known pellets from grazing and scavenging invertebrates from the nearshore of the southwestern Beaufort Sea (D. Schneider pers. comm.). The particles were examined with light and scanning electron microscopy for enumeration, morphology, and composition. The source animals for the fecal material collected in the traps were identified by characteristics based on extensive collections of fecal pellets from experimental specimens of nearshore Crustacea from the western Beaufort Sea (Schneider \& Koch 1979). Schneider (pers. comm.) based his identifications on the light color, encapsulating membrane, length, and diameter of the pellets.

In situ temperature and salinity were measured through the dive hole during the study period with an electrodeless salinometer (Kahl Scientific Instrument
Corporation Model RS5-3), modified to read temperatures to $-2.0^{\circ} \mathrm{C}$. The sensor was lowered to depths approximately $30 \mathrm{~cm}$ below the ice-water interface and above the sediments to minimize interference with the inductive salinometer sensor (Kahl Scientific Instrument Corp., 1975). Measurements were made at $1.0 \mathrm{~m}$ intervals between the ice and sediments.

\section{RESULTS}

\section{Environment}

The study area off Narwhal Island was a large flat pan of clean sea ice, anchored to the bottom by pressure ridges at the shoreward edge (Fig. 1). Water depth beneath the fast ice was approximately $8 \mathrm{~m}$. The sediments were silty sand $197 \%$ sand, $1 \%$ silt, $2 \%$ clay). Bottom currents as measured by a bottom drifter were slight under the ice, but appeared variable. The growth of sea ice at the dive station continued into the middle of May, reaching a thickness of $1.8 \mathrm{~m}$. Melting began with increased insolation toward the end of May and was proceeding rapidly at the end of the fieldwork in middle June. Snow cover was thin, averaging 2 to 3 $\mathrm{cm}$ in thickness; it disappeared by the end of May (Dougherty \& Poirot pers. comm.).

Table. 1. Environmental data measured $30 \mathrm{~cm}$ below the ice under-surface at the Narwhal Island ice station during spring 1980. Multiple measurements were made during four $24 \mathrm{~h}$ sampling periods

\begin{tabular}{|c|c|c|c|}
\hline Date & $\begin{array}{l}\text { Salinity } \\
(\% \circ) \\
(\bar{x} \pm \mathrm{SD})\end{array}$ & $\begin{array}{c}\text { Temperature } \\
\left({ }^{\circ} \mathrm{C}\right) \\
(\overline{\mathrm{x}} \pm \mathrm{SD})\end{array}$ & $\begin{array}{l}\text { No. of } \\
\text { obser- } \\
\text { vations }\end{array}$ \\
\hline $17 \mathrm{Apr}$ & 35.82 & -1.82 & 1 \\
\hline $19 \mathrm{Apr}$ & 35.20 & -1.55 & 2 \\
\hline $24 \mathrm{Apr}$ & 34.39 & -1.85 & 2 \\
\hline $28 \mathrm{Apr}$ & 34.70 & -2.00 & 1 \\
\hline $30 \mathrm{Apr}$ & $35.03 \pm 0.58$ & -2.00 & 8 \\
\hline 01 May & $34.70 \pm 0.69$ & $-1.83 \pm 0.03$ & 6 \\
\hline 05 May & 33.69 & -0.78 & 1 \\
\hline $07 \mathrm{May}$ & $35.72 \pm 0.05$ & $-2.00 \pm 0.00$ & 8 \\
\hline 08 May & 38.92 & -2.00 & 2 \\
\hline 11 May & 34.70 & -1.90 & 1 \\
\hline $15 \mathrm{May}$ & 35.36 & -2.00 & 1 \\
\hline 17 May & 35.30 & -2.00 & 1 \\
\hline 19 May & $34.29 \pm 1.21$ & $-2.00 \pm 0.00$ & 7 \\
\hline $20 \mathrm{May}$ & 33.82 & -1.08 & 1 \\
\hline 22 May & 33.59 & -2.00 & 1 \\
\hline $26 \mathrm{May}$ & 34.20 & -2.00 & 1 \\
\hline 29 May & 34.94 & -2.00 & 1 \\
\hline $31 \mathrm{May}$ & 35.04 & -2.00 & 1 \\
\hline $02 \mathrm{Jun}$ & $33.09 \pm 1.32$ & - & 8 \\
\hline 05 Jun & 33.68 & -2.00 & 1 \\
\hline 07 Jun & 32.30 & -1.46 & 1 \\
\hline 09 Jun & 2.81 & -0.44 & 1 \\
\hline $11 \mathrm{Jun}$ & 1.56 & -0.31 & 1 \\
\hline
\end{tabular}


Salinity remained fairly constant at the ice-water interface until 2 Jun 1980 when the melting of lowsalinity sea ice provided significant inputs of fresher water (Table 1). Salt content rapidly dropped from $33.68 \%$ on 5 Jun to $1.56 \%$ on 11 Jun. The water temperature at $30 \mathrm{~cm}$ below the ice rose slightly during this period; however, water temperatures did not rise significantly until early June. During April and early May the water just beneath the ice reached lower temperatures, though the minimum temperature is not known. When the salinity rose above $36.36 \%$ on 2 occasions the seawater temperature theoretically dropped below the $-2.00{ }^{\circ} \mathrm{C}$ minimum limit of the modified salinometer (Maykut 1985)

\section{Particle flux}

The particle flux to the bottom was relatively uniform throughout the entire spring period. There was no significant temporal variability in the total flux of mass, carbon, or nitrogen (Fig. 3A, B, C). The total mass flux was as high at the initial stages of the development of the ice biotic community as it was at the end in early June during the rapid ice melt. The $5 \mathrm{~d}$ collections ending on 3 and 11 May were highly variable with slightly larger mean mass; these data may have been affected by large, rare particles such as crustacean molts, algal strands or mats, and large fecal pellets. The organic carbon and nitrogen fluxes at the sediment surface also exhibited no significant trends with time (Fig. 3B, C). In fact, the striking result, particularly for carbon, was that the flux was essentially constant.

Only 2 types of large particle were identifiable: (1) fecal pellets from the epibenthic mysid Mysis relicta and the cryopelagic amphipod Pseudalibrotus litoralis (Schneider pers. comm.) (Fig. 4); and (2) molts from a diverse group of crustaceans (Table 2). Much of the other material appeared as pigmented areas on the filter surface and mainly consisted of fine-grained amorphous matter, although individual diatom tests could be recognized by SEM. The $M$. relicta pellets contained a complex matrix of generally unidentifiable material, though some diatom tests and possibly crustacean fragments were present (Fig. 4). The $P$. litoralis pellets collected in late May were comprised almost entirely of numerous ice diatom tests of Navicula transitans and Nitzschia (?)cylindrus (Horner pers. comm.).

The dense pellets formed by the epibenthic mysid Mysis relicata (Schneider pers. comm.) were captured in the traps at about the same low numbers throughout the season, although their flux decreased during the last collection period (Fig. 5).

On the other hand, smaller fecal pellets from Pseudalibrotus litoralis peaked in abundance on 29
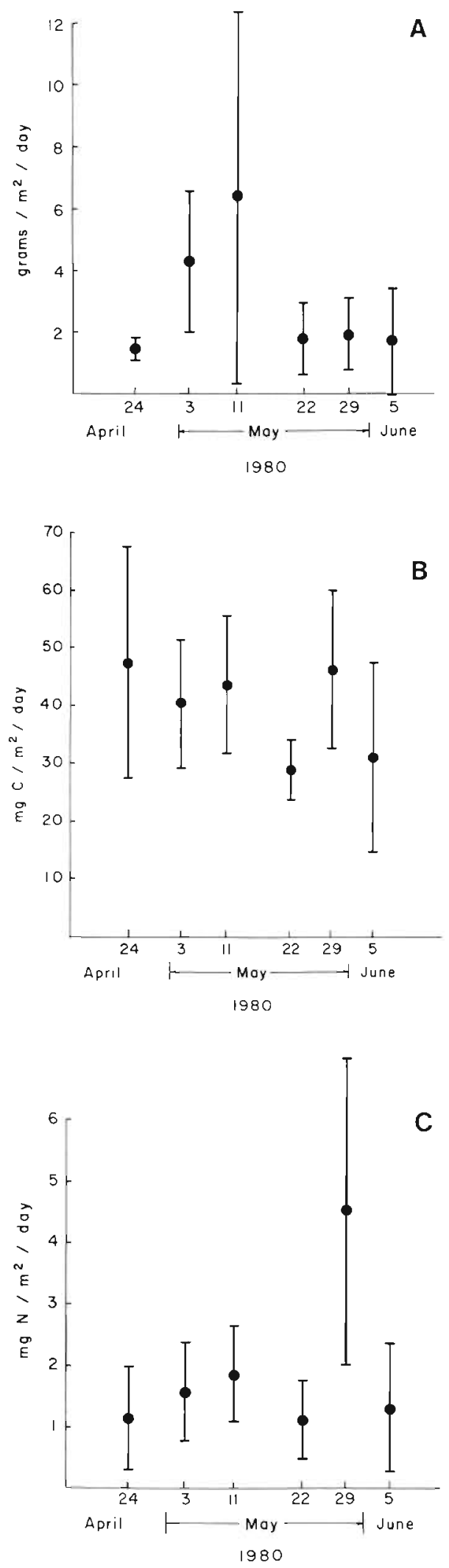

Fig. 3. (A) Total particle flux; (B) carbon flux; (C) nitrogen flux (all $\mathrm{g} \mathrm{m}^{-2} \mathrm{~d}^{-1}$ ) at each sampling period (mean \pm 2 standard deviations). Retrieval dates of particle traps are indicated 

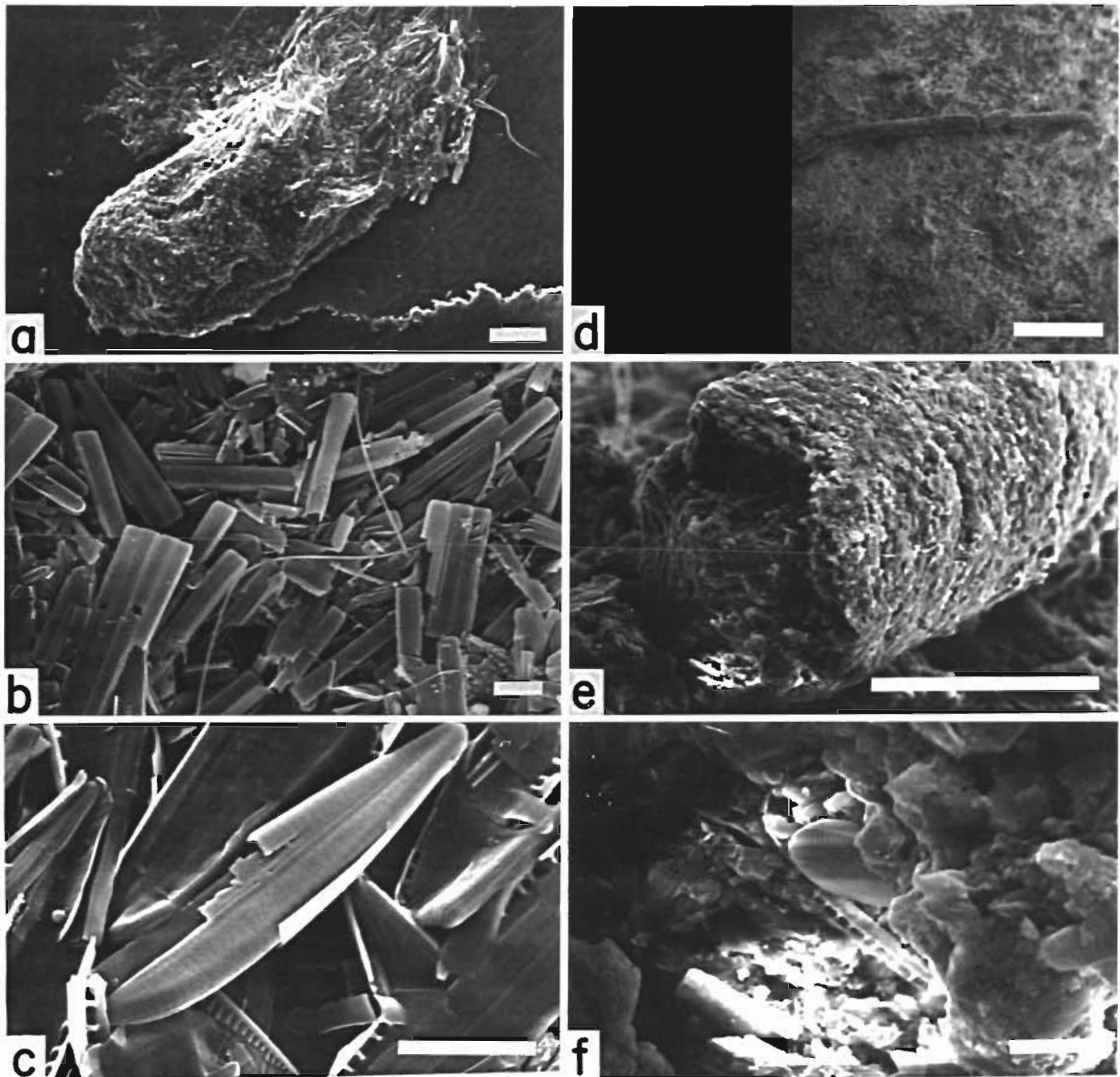

Fig. 4. (a to c) Pseudalibratus (=Onisimus) Litoralis and (d to f) Mysis relicta. Scanning electron micrographs of fecal pellets. Bars $\mathrm{a}$ and $\mathrm{e}=100 \mu \mathrm{m} ; \mathrm{b}, \mathrm{c}$, and $\mathrm{f}=10 \mu \mathrm{m}_{i} \mathrm{~d}=1000 \mu \mathrm{m}$. Note the high concentration of diatom frustules in the $P$. litoralis pellets

May and then decreased to nearly zero (Schneider pers. comm.). (Fig. 5). The size of these latter pellets formed a bimodal distribution, and the large and small pellets demonstrate opposing temporal trends (Fig. 6). There was a decreasing flux of large peliets, presumably resulting from adult amphipods dying during the spring and release of young (Boudrias \& Carey unpubl.). Small P. litoralis pellets, probably from juveniles feeding on the under-surface of the ice, increased in number during the same period. The fluxes of both size categories dropped to low levels during the last collection period. The flux of crustacean molts increased during the first half of the study, then declined in mid-May (Fig. 5). By early June a mean of
32 molts $\mathrm{m}^{-2} \mathrm{~d}^{-1}$ were recorded. The molts throughout the study period were from several taxa of small crustaceans.

\section{DISCUSSION}

Although patchy, ice algal communities show early and sometimes significant primary production. The production of the ice algae has been reported to contribute less than $1 \%$ and up to $40 \%$ of the annual carbon fixed by marine plants in the arctic ecosystem (Alexander 1974, Horner 1977, Horner \& Schrader 1982, Horner 1985). Because this late spring production on 
Table 2. Abundance of large, identifiable particles per bottom particle trap at Narwhal Island ice station, 1980. Three filters (A, B \& C) from each trap deployment were analyzed

\begin{tabular}{|c|c|c|c|c|c|c|c|c|c|c|c|}
\hline \multirow{2}{*}{$\begin{array}{l}\text { Retrieval } \\
\text { date }\end{array}$} & & \multirow{2}{*}{$\begin{array}{l}\text { Crusta- } \\
\text { cean } \\
\text { molts }\end{array}$} & \multicolumn{2}{|c|}{ Fecal pellets } & \multicolumn{5}{|c|}{ Swimmers } & \multirow[t]{2}{*}{ Eggs } & \multirow{2}{*}{$\begin{array}{l}\text { Sand } \\
\text { grains }\end{array}$} \\
\hline & & & $\begin{array}{c}P \\
\text { litoralis }\end{array}$ & $\begin{array}{c}M \\
\text { relicta }\end{array}$ & $\begin{array}{l}\text { Gam- } \\
\text { marid }\end{array}$ & $\begin{array}{l}\text { Cala- } \\
\text { noid }\end{array}$ & $\begin{array}{l}\text { Harpac- } \\
\text { ticoid }\end{array}$ & $\begin{array}{c}\text { Cuma- } \\
\text { cean }\end{array}$ & $\begin{array}{l}\text { Iso- } \\
\text { pod }\end{array}$ & & \\
\hline $24 \mathrm{Apr}$ & (A) & 3 & 54 & 7 & 0 & 0 & 0 & 0 & 0 & 0 & + \\
\hline $24 \mathrm{Apr}$ & (B) & 25 & 113 & 10 & 1 & 1 & 0 & 0 & 0 & 1 & ++ \\
\hline $24 \mathrm{Apr}$ & (C) & 10 & 51 & 8 & 2 & 0 & 3 & 0 & 0 & 0 & ++ \\
\hline 03 May & (A) & 13 & 60 & 2 & 0 & 0 & 0 & 0 & 0 & 0 & \\
\hline 03 May & (B) & 1 & 27 & 11 & 0 & 0 & 0 & 0 & 0 & 0 & + \\
\hline 03 May & (C) & 88 & 50 & 4 & 0 & 0 & 3 & 1 & 0 & 0 & \\
\hline 11 May & (A) & 64 & 84 & 11 & 0 & 0 & 2 & 0 & 0 & 0 & \\
\hline 11 May & (B) & 62 & 119 & 7 & 3 & 0 & 2 & 0 & 0 & 0 & \\
\hline 11 May & (C) & 26 & 89 & 5 & 0 & 0 & 0 & 0 & 0 & 0 & \\
\hline 22 May & (A) & 9 & 144 & 7 & 1 & 2 & 0 & 0 & 0 & 0 & \\
\hline 22 May & (B) & 1 & 113 & 5 & 0 & 0 & 0 & 0 & 1 & 0 & \\
\hline 22 May & (C) & 41 & 79 & 11 & 0 & 0 & 0 & 0 & 1 & 2 & \\
\hline 29 May & (A) & 15 & 156 & 5 & 0 & 0 & 0 & 0 & 0 & 0 & \\
\hline 29 May & (B) & 4 & 113 & 12 & 0 & 0 & 0 & 0 & 0 & 0 & \\
\hline 29 May & (C) & 4 & 134 & 5 & 0 & 0 & 0 & 0 & 0 & 1 & \\
\hline 05 Jun & (A) & 0 & 158 & 0 & 0 & 0 & 0 & 0 & 0 & 0 & \\
\hline 05 Jun & (B) & 0 & 0 & 1 & 0 & 0 & 0 & 0 & 0 & 0 & \\
\hline 05 Jun & (C) & 6 & 110 & 1 & 0 & 0 & 0 & 0 & 0 & 0 & \\
\hline
\end{tabular}

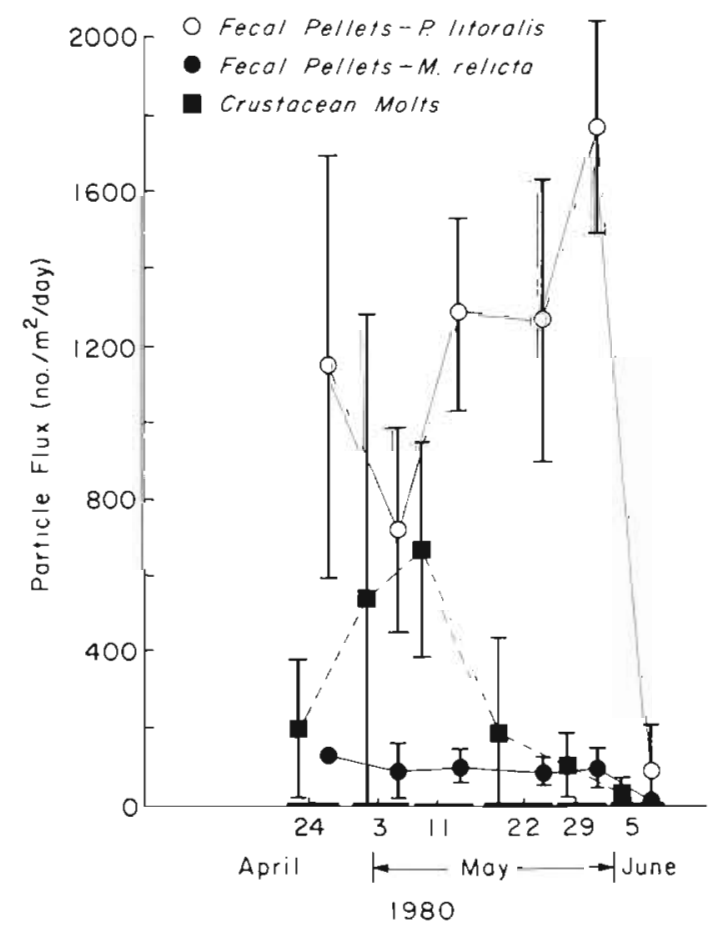

Fig. 5. Fecal pellet and molt flux (no. $\mathrm{m}^{-2} \mathrm{~d}^{-1}$ ) at each sampling period (mean \pm 2 standard deviations). Retrieval dates of particle traps are indicated

the under-surface of sea ice occurs before plant production can be supported in the water column or on the sediments in shallow water, the ice algae become an

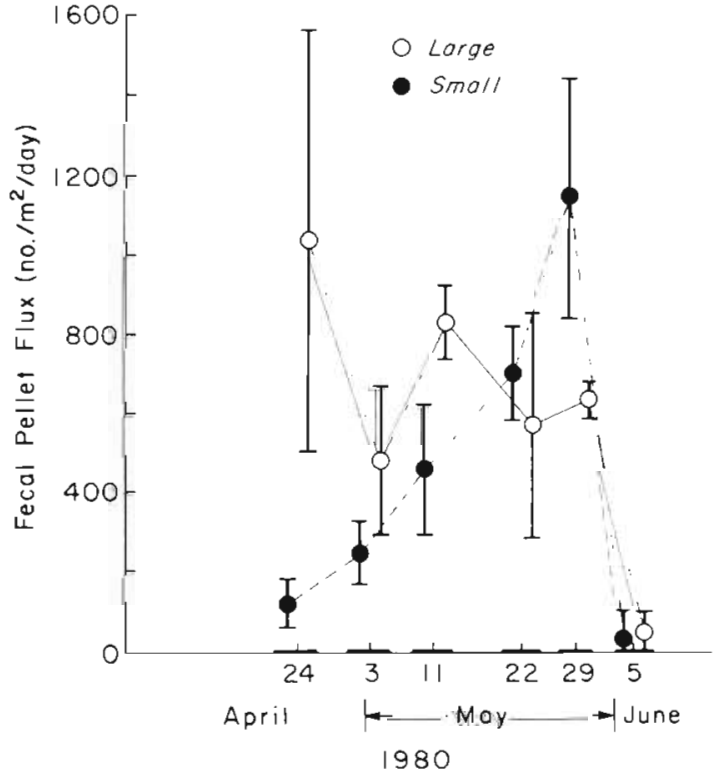

Fig. 6. Fecal pellet flux (no. $\mathrm{m}^{-2} \mathrm{~d}^{-1}$ ) at each sampling period (mean \pm 2 standard deviations). Large pellets are from adult $P$ seudalibrotus litoralis, and small pellets from juvenile $P$. litoralis. Retrieval dates of the particle traps are indicated

early source of food which significantly extends the arctic growing season for certain fauna (Dunbar 1977 , Alexander \& Chapman 1981). The ice under-surface supports large faunal populations that prey and scavenge on one another early in the season and then graze on the algae in late May and early June at the 
height of the ice algal bloom (Cross 1982, Carey \& Montagna 1982, Kern \& Carey 1983, Carey 1985, Carey \& Boudrias 1987). These animal populations in turn form a short food web that links the under-ice fauna to fishes and to seabirds and seals (Bradstreet 1982, Bradstreet \& Cross 1982).

Ice algal primary productivity and chlorophyll a concentrations at the Narwhal Island station trended upward from early May through early June, although marked peaks occurred in both months (Horner \& Schrader 1982). Incident light intensity appeared to be the controlling factor. Increasing insolation and decreasing snow cover caused the productivity peaks, although storms decreased the light flux which, in turn, lowered the productivity rate. A storm during the second week of May decreased ice algal primary productivity (Horner \& Schrader 1982).

Various workers have suggested that the ice biotic assemblage is an early source of food for the arctic benthos and that there is a downward pulse of organic flux during ice melt and break-up (Golikov \& Scarlato 1973. Alexander 1980, 1981, Horner \& Schrader 1982). Our data indicate that this community does provide an early source of food for the benthos, even in April at the time of the first trap deployment. However, the flux rate is low. In contrast, studies in the Baltic Sea have shown that after the spring phytoplankton bloom fecal pellets and particulate detritus rapidly reach the sea floor as a pulse. The organic matter is then quickly metabolized by the benthos, particularly by benthic bacteria (Smetacek 1980, Gassmann \& Gillbricht 1982, Graf et al. 1982). In the Beaufort Sea benthic bacterial activity is reduced during winter, presumably caused by low organic input to the sea floor (Atlas \& Griffiths 1984).

The lack of temporal trends does not support the hypothesis that there is an increased downward flux during the latter stages of ice melt. It is possible that field activities had to be curtailed before the hypothesized sudden and widespread downward flux of ice algae took place at the time of ice break-up. During advanced stages of ice melt, offshore sampling is extremely difficult; so particle flux data are unavailable at this study site under these environmental conditions (Carey et al. 1984, Legendre pers. comm., Cota pers. comm.). However, divers observations in early June indicate that the ice algal layer at the study site had almost disappeared at the time of the last particle trap deployment (Dougherty \& Poirot pers. comm.), and by mid-June the ice algal layer was no longer visible (Horner \& Schrader 1982). Furthermore, it was noted that turbidity in the water column was high, perhaps caused by the ice algal cells remaining in suspension after being released from the ice.

These observations suggest that downward transport of this material is depressed. Results from Pett et al.
(1983) also support this conclusion. They reported no large flux of particulate carbon or nitrogen to the bottom during the rapid ice melt period at similar shallow depths in the eastern Beaufort Sea. Horner (1985) states that there are conflicting views in the literature about the fate of ice algae after ice melt. Clearly, more detailed studies are needed to determine the fate of these microalgae in different geographic areas (Horner 1985).

How much of the ice algal production actually reaches the benthos? From $<0.2$ to $2.6 \mathrm{mg} \mathrm{C} \mathrm{m}^{-2} \mathrm{~h}^{-1}$ were produced at the ice under-surface off Narwhal Island during spring 1980 (Horner \& Schrader 1982). During this period, 0.016 to $0.025 \mathrm{mg} \mathrm{C} \mathrm{m}^{-2} \mathrm{~h}^{-1}$ settled into the traps placed on the bottom (1 to $10 \%$ of the carbon fixed by the ice algae). The coupling, then, of carbon production in the ice to the shallow sea floor beneath is weak, and significant amounts of organic carbon and nitrogen do not reach the sediments. Much of the algal production, if not lost by advection, could be grazed in situ, particularly by the amphipods. The flux of particulate carbon can be significantly higher in protected coastal bays at temperate latitudes subject to urban eutrophication. For example, during April through June average monthly fluxes of about 3.1 to 6.4 $\mathrm{g} \mathrm{C}$ and 0.3 to $1.2 \mathrm{~g} \mathrm{~N} \mathrm{~m}^{-2}$ were measured at $20 \mathrm{~m}$ depth in Bedford Basin, Nova Scotia (Hargrave 1980). On the other hand, fluxes measured above the turbulent bottom layer during late summer in non-eutrophic bays, such as St. Georges Bay in the southern Gulf of St. Lawrence, were similar to rates observed in our study ( 45 to $60 \mu \mathrm{g} \mathrm{C} \mathrm{m}^{-2} \mathrm{~d}^{-1}$ ) (Hargrave \& Phillips 1986).

The relative energetic importance of the spring organic flux from the ice community to the southern Beaufort Sea sediments is unknown. Primary production data are scattered in space, time, and environment for this area; therefore, a rigorous comparison of primary production and particle fluxes for spring and other seasons cannot be made. Horner \& Schrader (1982) state that a spring phytoplankton bloom has not been measured after ice break-up; they suggest that there may be a gradual build-up in primary productivity when sufficient light levels are reached after ice breakup. The available data tend to support the hypothesis that the annual primary production is low in arctic waters (Horner \& Schrader 1982, Subba Rao \& Platt 1984) and that consequently, the standing stock of benthos on the inner shelf is low (Carey \& Ruff 1977).

Observations by the divers indicate that a turbid, lowsalinity layer from the spring discharge after ice breakup of the nearby Sagavanvirtok River was beginning to move beneath the ice at the Sea Ice-80 dive station (Dougherty \& Poirot pers. comm.). Combined with the density barrier of a sharp halocline, there may have been enough lateral advection near the ice to export ice 
algal cells and mats beyond the confines of the experimental ice floe. Howeyer, the currents measured earlier in the season under fast ice (Aagaard 1984) were slight at $10 \mathrm{~m}$ depth. These factors could have prevented a rapid and significant flux of algal material to the sediments during the melt period.

In the present study Mysis relicta, a benthic species, was not collected at the ice under-surface or in midwater, although Holmquist (1963) reports capture of this species in a plankton haul (Griffiths \& Dillinger 1981. Carey unpubl. data). M. relicta swimming in the bottom water layer above the traps were probably the source for the dense fecal pellets collected by the traps. Sedimented detritus is probably the main food source for this epibenthic species.

Though the flux of Pseudolibrotus Iitoralis fecal pellets to the bottom was low in April and did not reach its maximum until the end of May, the amphipods were actively feeding at the ice under-surface throughout the spring (Carey \& Boudrias 1987). The early spring diet of the lysianassid amphipod appeared to consist almost entirely of crustacean fragments that were eaten as live prey or as carcasses in the ice environment. The $P$. litoralis mouthparts are well-adapted for utilizing food from diverse sources. Gastro-intestinal tract and fecal pellet analyses demonstrated that organisms were feeding on ice diatoms at the end of the season. It is of interest that the flux of $P$. litoralis fecal pellets to the bottom abruptly diminished at the time of the sudden decrease of salinity under the ice. The data suggest either that the amphipods left the cryopelagic environment and returned to the bottom because of the decrease of salinity or that the oceanographic conditions prevented a significant downward flux of fecal pellets. However, P. litoralis is adapted to live under a wide range of salinity conditions (Holmquist 1963).

The species that most benefit from the early spring ice algal production are those that are adapted to utilize the ice undersurface as a habitat and for a food source. Benthic animals residing on the ocean floor, even in shallow water, apparently receive only small amounts of food exported from the ice community. However, the food that does reach the benthos provides these animals with continuous rations that are available earlier than either the phytoplankton or the benthic algal production

Future flux studies beneath sea ice should be extended through ice-break-up with small inflatable boat operations deployed from shore or from icebreakers to determine whether there is an eventual pulse of ice algal material to the bottom. Water bottle collections in the water column would document the fate of the ice algae during the melt season. In addition chlorophyll $a$ and $\mathrm{CaCO}_{3}$ should be measured in the trapped material to provide further information about the quality and source of the particles. In situ current meters should be deployed beneath the ice concurrently with the flux studies

Acknowledgements. The valuable field assistance of J.C. Kern, R. E. Ruff, R. H. Scott, and K. R. Walters is gratefully acknowledged; SCUBA divers were $\mathrm{R}$. Poirot and $\mathrm{J}$. Dougherty. K. Persons, S. Petersen, and NOAA helicopter crews are thanked for logistical support in the field. R. E. Ruff is thanked for his invaluable assistance in the laboratory and with the trap design. A. H. Soeldner performed the SEM photography; D. R. Hancock analyzed the sediments; D. Schneider (Western Washington University, Bellingham, Washington, USA) identified the fecal pellets, and R. A Horner (4211 NE 88 St., Seattle, Washington), the ice microalgae. Drawings were done by D. Prosser. Discussions with C. B. Miller, R. E. Ruff, R. A. Horner, and B. T. Hargrave were very helpful, and the manuscript benefited from comments by L. F Small, E. M. Carey, and 4 anonymous reviewers. The study was supported by the Minerals Management Service through an interagency agreement with the National Oceanic and Atmospheric Administration as part of the Alaskan Outer Continental Shelf Environmental Assessment Program

\section{LITERATURE CITED}

Aagaard, K. (1984). The Beaufort undercurrent. In: Barnes, P. W., Schell, D. M., Reimnitz, E. (ed.) The Alaskan Beaufort Sea: ecosystems and environments. Academic Press, Orlando, p. 47-71

Alexander, V (1974). Primary productivity regimes of the nearshore Beaufort Sea, with reference to the potential roles of the ice biota. In: Reed, J. C., Sater, J. E. (ed.) The coast and shelf of the Beaufort Sea. Arctic Institute of North, America, Arlington, Virginia, p. 609-632

Alexander, $V$ (1980). Interrelationships between the seasonal sea ice and biological regimes. Cold Regions Sci. Tech. 2: $157-178$

Alexander, V (1981). Ice-biota interactions: an overview. In: Hood, D. W., Calder, J. A. (ed.) The eastern Bering Sea shelf; oceanography and resources, Vol. 2. Univ. Washington Press, Seattle, p. 757-761

Alexander, V., Chapman, T. (1981). The role of epontic algal communities in Bering Sea ice. In: Hood, D. W., Calder, D. A. (ed.) The eastern Bering Sea shelf: oceanography and resources. NOAA Office of Mar. Pollution Assess. Anchorage, p. 773-780

Atlas, R. M. Griffiths, R. P. (1984). Bacterial populations in the Beaufort Sea. In: Barnes, P. W., Schell, D. M., Reimnitz, E. (ed.) The Alaskan Beaufort Sea: ecosystems and environments. Academic Press, Orlando, P. 327-345

Barnes, P. W., Reimnitz, E. (1974). Sedimentary processes on arctic shelves off the northern coast of Alaska. In: Reed J. C., Sater, J. E. (ed.) The coast and shelf of the Beaufort Sea. Arctic Institute of North America, Arlington, Virginia p. $439-476$

Bishop, J. K. B., Edmond, J. M. (1976). A new large volume filtration system for the sampling of oceanic particulate matter. J. mar. Res. 34: 181-198

Bloesch, J., Burns, N. M. (1980). A critical review of sedimentation trap technique. Schweiz. Z. Hydrol. 42: 15-55

Booth, J. A. (1984). The epontic algal community of the ice edge zone and its significance to the Davis Strait ecosystem. Arctic 37 $234-243$ 
Bradstreet, M. S. W (1982). Occurrence, habitat, use and behaviour of seabirds, marine mammals, and arctic cod at the Pond Inlet ice edge. Arctic 35: 28-40

Bradstreet, M. S. W., Cross, W. E. (1982). Trophic relationships at high Arctic ice edges. Arctic 35: 1-12

Carey, A. G., Jr (1985). Marine ice fauna: Arctic. In: Horner, R. A. (ed.) Sea ice biota. CRC Press, Boca Raton, Florida, p. $173-190$

Carey, A. G., Jr., Boudrias, M. A. (1987). Feeding ecology of Pseudalibrotus (=Onisimus) litoralis kroyër (Crustacea: Amphipoda) on the Beaufort Sea inner continental shelf. Polar Biol. 7

Carey, A. G., Jr., Boudrias, M. A., Kern, J. C., Ruff, R. E. (1984). Selected ecological studies in continental shelf benthos and sea ice fauna in the southwestern Beaufort Sea. In: U. S. Dept Commerce, NOAA/OCSEAP Final Reports of Principal Investigators. Vol. 23. Anchorage, p. 1-164

Carey, A. G., Jr., Montagna, P. A. (1982). Arctic sea ice faunal assemblage: first approach to description and source of the underice meiofauna. Mar. Ecol. Prog. Ser. 8: 1-8

Carey, A. G., Jr., Ruff, R. E. (1977). Ecological studies of the benthos in the western Beaufort Sea with special reference to bivalve molluscs. In: Dunbar, M. J. (ed.) Polar Oceans. Arctic Institute of North America, Calgary, Alberta, p 505-530

Carey, A. G., Jr, Ruff, R. E., Scott, P. H., Walters, K. R., Kern, J. C. (1981). The distribution, abundance, composition and variability of the western Beaufort Sea benthos. In: U. S. Dept. Commerce, NOAA/OCSEAP Annual Reports of Principal Investigators, Vol. II. Juneau, Alaska, p. 27-363

Carey, A. G., Jr., Scott, P. H., Walters, K. R. (1984). Distributional ecology of shallow southwestern. Beaufort Sea (Arctic Ocean) bivalve Mollusca. Mar Ecol. Prog. Ser. 17. $125-134$

Conover, R. J., Herman, A. W., Prinsenberg, S. J., Harris, L. R (1986). Distribution and feeding by the copepod Pseudocalanus under fast ice during the arctic spring Science 232: 1245-1247

Cross, W. E. (1982). Under-ice biota at the Pond Inlet ice edge and adjacent fast ice areas during spring. A.rctic 35: 13-27

Dunbar, M. J. (1977). The evolution of polar ecosystems. In Llano, G. A. (ed.) Adaptations within Antarctic ecosystems, Proceedings third SCAR Symposium on Antarctic Biology Smithsonian Institution, Washington, D. C., p. 1063-1076

Gardner, W D. (1980). Field assessment of sediment traps. J. mar. Res. 38: 41-52

Gassmann, G., Glllbricht, M. (1982). Correlations between phytoplankton, organic detritus and carbon in North Sea waters during the Fladenground Experiment (FLEX 76). Helgoländer Meeresunters. 35: 253-262

Golikov, A. N., Scarlato, O. A. (1973). Comparative characteristics of some ecosystems of the upper regions of the shelf in tropical, temperate and arctic waters. Helgoländer wiss. Meeresunters, 24: 219-234

Graf, G., Bengstsson. Diesner, U., Schulz, R., Theede, H (1982). Benthic response to sedimentation of a spring phytoplankton bloom: process and budget. Mar. Biol. 67: 201-208

Grainger, E. H., Mohammed, A. A., Lovrity, J. E. (1985). The sea ice fauna of Frobisher Bay, Arctic, Canada. Arctic 38: 23-30

Green, K. A. (1976). Simulation of the pelagic ecosystem of the Ross Sea, Antarctica: a time varying compartmental model. Univ. Microfilms International, Ann Arbor, Michigan

Griffiths, W. B., Dillinger, R. E. (1981). Beaufort Sea barrier island-lagoon ecological processes studies: final report.
Simpson lagoon. In: U. S. Dept. Commerce, NOAA/ OCSEAP Final Report of Principal Investigators. Vol. 8: Biological studies. Anchorage, Alaska, p. 1-198

Hargrave, B. T (1980). Factors affecting the flux of organic matter to sediments in a marine bay. In: Tenore, $K$. R., Coull, B. C. (ed.) Marine benthic dynamics. Univ. South Carolina Press, Columbia, p. 243-263

Hargrave, B. T., Philipps, G. A. (1986). Dynamics of the benthic food web in St. Georges Bay, southern Gulf of St Lawrence. Mar Ecol. Prog. Ser. 31: 277-294

Holmquist, C. (1963). Some notes on Mysis relicta and its relatives in northern Alaska. Arctic 16: 109-128

Honjo, S. (1978). Sedimentation of materials in the Sargasso Sea at a 5,367 m deep station. J. mar. Res. 36: 469-492

Honjo, S. (1980). Material fluxes and modes of sedimentation in the mesopelagic and bathypelagic zones. J. mar. Res. 38: 53-97

Horner, R. A. (1977). History and recent advances in the study of the ice biota. In: Dunbar, M. J. (ed.) Polar Oceans. Arctic Institute of North America, Arlington, Virginia, p. 269-284

Horner, R. (1984). Phytoplankton abundance, chlorophyll a, and primary productivity in the western Beaufort Sea. In: Barnes, P. W., Schell, D. M., Reimnitz, E. (ed.) The Alaska Beaufort Sea: ecosystems and environments. Academic Press, Orlando, Florida, p. 295-300

Horner, R. A. (1985). Ecology of ice microalgae. In: Horner, R A. (ed.) Sea ice biota. CRC Press, Boca Raton, Florida, p. $147-157$

Horner, R. A., Schrader, G. C. (1982). Relative contributions of ice algae, phytoplankton and benthic microalgae to the primary production in nearshore regimes of the Beaufort Sea. Arctic 35: 485-503

Kahl Scientific Instrument Corporation (1975). Instructions. Electrodeless in-situ Salinometer, Catalog \# 118WA300, Model RS5-3, Pt. No. 31544D. El Cajon, California

Kern, J. C., Carey, A. G., Jr (1983). The faunal assemblage inhabiting seasonal sea ice in the nearshore Arctic Ocean with emphasis on copepods. Mar. Ecol. Prog. Ser 10: 159-167

Knauer, G. A., Martin, J. H. (1981). Primary production and carbon-nitrogen fluxes in the upper $1,500 \mathrm{~m}$ of the northeast Pacific. Limnol. Oceanogr. 26: 181-186

Knauer, G. A., Martin, J. H., Bruland, K. W. (1979). Fluxes of particulate carbon, nitrogen, and phosphorus in the upper water column of the northeast Pacific. Deep Sea Res. 26: 97-108

Kovacs, A., Mellor, M. (1974). Sea ice morphology and ice as a geological agent in the southern Beaufort Sea. In: Reed, $J$. C. Sater, J. E. (ed.) The coast and shelf of the Beaufort Sea. Arctic Institute of North America, Arlington, Virginia, p. $113-161$

Matthews, J. B. (1981). Observations of surface and bottom currents in the Beaufort Sea near Prudhoe Bay. J. geophys Res. 86: 6653-6660

Maykut, G. A. (1985). The ice environment. In. Horner, R. A. (ed.) Sea ice Biota. CRC Press, Boca Raton, Florida, p. 21-82

Mel'nikov, I. A., Kulikov. A. S. (1980). The cryopelagic fauna of the Central Arctic Basin. In: Biologiya Tsentral nogo Arkticheskogo Baseina, Akademiya Nauk SSSR, Moscow, Nauka Publishing House. Transl. Bureau, Dept Secretary of State Canada, 1983, p. 97-11

Nemoto, T., Harrison, G. (1981). High latitude ecosystems. In: Longhurst, A. R. (ed.) Analysis of marine ecosystems. Academic Press, London, p. 95-126

Pett, R. J, Vickers, G. P., Acreman, J. C., Ethier, A. G. (1983) 
A seasonal study of the epontic and planktonic communities near the Issungnak artificial island and McKínley Bay in the Canadian Beaufort Sea. Contract ISZ81-00026, Department of Supply and Services, Canada Report by Arctic Laboratories Ltd., Sydney

Reimnitz, E., Barnes, P. W. (1974). Sea ice as a geologic agent. In: Reed, J. C., Sater. J. E. (ed.) The coast and shelf of the Beaufort Sea. Arctic Institute of North America, Arlington, Virginia, p. 301-353

Reimnitz, R., Toimil, L., Barnes, P. (1978). Arctic continental shelf morphology related to sea-ice zonation, Beaufort Sea, Alaska. Mar. Geol. 28: 179-210
Schneider, D. E., Koch, H. (1979). Trophic relationships of the arctic shallow water marine ecosystem. In: U.S. Dept. Commerce, NOAA/OCSEAP Annual Reports of Principial Investigators. Vol. III. Boulder, Colorado, p. 503-542

Smetacek, V S. (1980). Zooplankton standing stock, copepod faecal pellets and particulate detritus in Kiel Bight. Estuar. coast. mar Sci. 11. $477-490$

Subba Rao, D. V., Platt, T (1984). Primary production in arctic waters. Polar Biol. 3: 191-201

Suess, E. (1980). Particulate organic carbon flux in the oceans - surface productivity and oxygen utilization. Nature, Lond 288: $260-263$

This article was submitted to the editor; it was accepted for printing on August 12, 1987 